\title{
Physiotherapeutic approach in managing a patient after below-knee amputation due to diabetic foot syndrome
}

\section{ABSTRACT}

Diabetic foot syndrome (DFS) is the most common complication in the course of diabetes and can lead to loss of the lower limb. In case of amputation an important role is played by physiotherapeutic procedures and secondary prevention. The article presents the case of a 75-year-old man with type 2 diabetes, after below- knee amputation of the left lower limb in the course of DFS. The patient underwent a physiotherapeutic treatment consisting of a number of procedures aimed at re-education of the gait function and learning to use the prosthesis. It played an important role in restoring social and professional activities of the patient and thus enabled him to return to his usual life. (Clin Diabetol 2017; 6, 6: 218-220)

Key words: type 2 diabetes, diabetic foot syndrome, lower limb amputations, physiotherapy, rehabilitation

\section{Introduction}

Diabetic foot syndrome (DFS) is the most common complication in the course of diabetes. According to the World Health Organization (WHO) it is defined as

Address for correspondence: dr n. med. Bogumił Wolnik

Klinika Nadciśnienia Tętniczego i Diabetologii

Uniwersyteckie Centrum Kliniczne w Gdańsku

Gdański Uniwersytet Medyczny

ul. Dębinki 7, 80-211 Gdańsk

e-mail: bwolnik@gumed.edu.pl

Translation: lek. Jędrzej Toczko

Clinical Diabetology 2017, 6, 6, 218-220

DOI: $10.5603 /$ DK.2017.0036

Received: 10.01.2018 the presence of infection, ulceration and/or deep tissue destruction, concomitant with features of neuropathy and ischemia of various degrees [1]. Diabetes is one of the most common causes of lower limb amputations [2-4]. In $80 \%$ of cases the amputation is preceded by ulceration. The risk of an ulceration occurring in a patient's lifetime is $10-25 \%$, the rate of limb amputation procedures in diabetic patients amounts to $25-50 \%$ and the likelihood of an amputation is almost 30 times higher than in non-diabetic patients [5-7]. Importantly, amputation does not indicate the end of DSF. A five year mortality rate after the surgery can reach $80 \%$ of patients, which is why rehabilitation and secondary prevention should be greatly emphasized [8].

This article presents a case report of a type 2 diabetes patient, after below-knee amputation in course of DSF, who underwent physiotherapeutic treatment as preparation for prosthesis implementation.

\section{Case report}

A 75 year old male geodesist with a 16 year history of type 2 diabetes was subject to a physiotherapeutic treatment in his third month after a below-knee amputation of the left lower limb. First two months of the treatment consisted of household physiotherapy twice a week. The patient was later admitted to a day care rehabilitation ward, where he exercised 1-2 hours a day for three weeks. Prosthesis implementation occurred 6 months after the procedure, in accordance with guidelines.

The therapy was mainly aimed at re-education of the gait function and learning to use the prosthesis. Specific goals included stump shaping and desensitization, learning of axial weight bearing, postopera- 
Table 1. Longitudinal measurements

\begin{tabular}{|c|c|c|}
\hline & RLE & LLE \\
\hline Relative lenght [cm] & 91 & \\
\hline \multicolumn{3}{|l|}{ (from the anterior superior pelvic spine } \\
\hline \multicolumn{3}{|l|}{ to the medial malleolus) } \\
\hline Absolute lenght $[\mathrm{cm}]$ & 83 & \\
\hline \multicolumn{3}{|l|}{ (from the greater trochanter of the femur } \\
\hline \multicolumn{3}{|l|}{ to the lateral) } \\
\hline Femor lenght $[\mathrm{cm}]$ & 43 & 43 \\
\hline \multicolumn{3}{|l|}{ [from the greater trochanter of the femur } \\
\hline \multicolumn{3}{|l|}{ to the joint space of the knee (laterally)] } \\
\hline Crus lenght $[\mathrm{cm}]$ & 40 & \\
\hline \multicolumn{3}{|l|}{ [from the joint space of the knee (medially) } \\
\hline \multicolumn{3}{|l|}{ to the medial] } \\
\hline Stump lenght $[\mathrm{cm}]$ & & 22 \\
\hline [from the joint space of the knee (medially)] & & \\
\hline
\end{tabular}

Table 2. Circumferential measurements

\begin{tabular}{lcc}
\hline & RLE & LLE \\
\hline $\begin{array}{l}\text { First femoral circumference [cm] } \\
\text { (the largest thigh circumference }\end{array}$ & 48 \\
$-25 \mathrm{~cm}$ from the base of the patella) & & \\
Second femoral circumference [cm] & 44 & 44 \\
(thigh circumference $6 \mathrm{~cm}$ from the & & \\
base of the patella) & 41 & 41 \\
Knee circumference [cm] & & \\
(through lateral knee joint space and & \\
the patella) & & \\
First crural circumference [cm] & & \\
(the circumference of the crus and the stump & \\
17 cm from the base of the patella) &
\end{tabular}

tive scar formation, maintaining correct joint motion ranges, increasing both lower and upper limb muscle strength, all in order to enable efficient crutch walking.

Longitudinal (Tab. 1) and circumferential (Tab. 2) measurements were taken during physical examinations. A visual evaluation as well as an assessment of muscle strength and joint motion range of the lower limbs was also performed.

The above measurements disclose an asymmetry in mass of the quadriceps femoris muscle, hamstrings muscles and adductor muscles between the left and right lower limb. The difference in first circumference was $4 \mathrm{~cm}$. However, the circumference of the medial head of left the quadriceps femoris muscle - the second femoral circumference - proved to be $44 \mathrm{~cm}$, similar to this of the right limb.
Subsequently, a muscle strength test - the Lovett's test - was performed. The test evaluates muscle strength, marking it on a 0 to 5 scale where 0 means no active muscle contraction and 5 stands for normal muscle strength, where active motion against full resistance is possible. Each muscle group was marked 4 on the scale [9].

Lastly, ranges of active and passive joint motions were evaluated. The results were normal for each joint.

\section{Physiotherapeutic approach Stump desensitization}

Desensitization is a crucial part of rehabilitation, as excessive pressure sensitivity may cause the patient to reject the orthopaedic equipment. This procedure includes, among others, classic stump massage, alternating warm and cold water exposure or rubbing the stump with a terry glove [10].

\section{Scar formation}

Stroking and friction - classic massaging techniques - were performed, starting peripherally towards the scar and in the opposite direction. Additionally, kneading, rolling, breaking up and moving techniques were used across the scar [10].

\section{Postural therapy - prophylaxis of contracture}

The patient was instructed on positions of the limb that protect the stump from incorrect stance, hence preventing contractures.

\section{Learning the appropriate stump bandaging}

The patient was educated on appropriate stump bandaging technique using the figure-of-eight wrap [10].

\section{Free, active movement exercises}

The therapy included a number of free active movement exercises with a full range of motion for both upper and lower limbs. It was aimed to maintain appropriate joint range motions, prevent contractures, increase muscle strength and improve cardiovascular performance. Learning to control the back and forth stump motion was also important.

\section{Active exercises against resistance}

Resistance exercises were performed to increase muscle strength within lower and upper limbs as well as abdominal muscles [11].

\section{Coordination and balance exercises}

Coordination and balance exercises were used as an important preparation to prosthesis assisted gait re-education [11]. 


\section{Postural re-education}

Enforcing correct body stance with appropriate head position - with no protraction tendencies, symmetrical shoulder posture without leaning forward, an appropriate chest arch, symmetrically posed lower limbs and correct upper limbs position with orthopaedic equipment - was a vital goal of therapy [11].

\section{Re-education of the gait}

All of the aforementioned procedures were connected by a single, most important therapeutic goal re-education of patient's gait, a crucial aspect of returning back to both personal and professional activities [12]. The patient was trained in a two point alternate crutch gait. The walking cycle begins with a step with the prosthesis equipped limb with contralateral crutch assistance. A second step with the opposite leg is then made, with a similar assistance of the contralateral crutch. Stair climbing re-education, non-assisted gait and slide stepping training followed in the educational process $[10,11]$.

\section{Effects of the therapy}

The main goal of gait re-education and prosthesis use training were achieved in the course of therapy. Specific aims were also reached. An increase in muscle mass of the thigh was observed. The first femoral circumference grew by $2 \mathrm{~cm}-$ to $50 \mathrm{~cm}$. Thus, the asymmetry between the lower limbs was reduced from 4 to $2 \mathrm{~cm}$ 's. Stump circumference reduced from 37.5 to $34 \mathrm{~cm}$. Due to systematic formation and mobilization, scar relaxation was achieved and no soft tissue adhesions occurred. Applied therapeutic procedures resulted in an increase of muscle strength in both lower and upper limbs as well as in postural muscles, improving prosthesis control and movement education. Postural re-education was also positively affected by the therapy.

The procedures performed played an important role in restoring patient's capabilities to these from before the surgery, allowing his return to both social and professional life.

\section{Summary}

An early start of rehabilitation in a patient after lower limb amputation in the course of diabetic foot syndrome is imperative to the process of preparations to prosthesis implementation. Physiotherapeutic treatment not only influences the shape and mass of the stump and post-operative scars, but also prepares individual muscle groups for functional prosthesis control. The essence of early implemented therapy is also to prevent a decrease in patient's physical endurance due to performed surgery, and to maintain or reinstate correct move patterns, by stimulating muscle memory.

The exercises schedule should be adjusted individually, in relation to non-modifiable factors such as patient's age and concomitant diseases, but also general activity levels and attitude towards the process of rehabilitation.

The fundamental of early prosthesis implementation should not be omitted, as it affects not only move patterns and muscle memory, but also plays a key role in returning the patient to family, social and professional activities.

In the case discussed, a complete recovery in professional and family life was achieved.

\section{Conflict of interest declaration}

The authors declare no conflict of interest.

\section{REFERENCES}

1. Korzon-Burakowska A. Zespól stopy cukrzycowej - patogeneza i praktyczne aspekty postępowania. Chor Serca Naczyń. 2007; 4(2): 93-98.

2. Reiber GE, Lipsky BA, Gibbons GW. The burden of diabetic foot ulcers. Am J Surg. 1998; 176(2A Suppl): 5S-510S, doi: 10.1016/ /s0002-9610(98)00181-0, indexed in Pubmed: 9777967.

3. Kayssi A, Dilkas S, Dance DL, et al. Rehabilitation Trends After Lower Extremity Amputations in Canada. PM R. 2017; 9(5): 494-501, doi: 10.1016/j.pmrj.2016.09.009, indexed in Pubmed: 27664402.

4. Marshall C, Barakat T, Stansby G. Amputation and rehabilitation. Surgery. 2016; 34(4): 188-191, doi: 10.1016/j.mpsur.2016.02.006.

5. Singh N, Armstrong DG, Lipsky BA. Preventing foot ulcers in patients with diabetes. JAMA. 2005; 293(2): 217-228, doi: 10.1001/ /jama.293.2.217, indexed in Pubmed: 15644549.

6. Ricco JB, Thanh Phong L, Schneider F, et al. The diabetic foot: a review. J Cardiovasc Surg (Torino). 2013; 54(6): 755-762, indexed in Pubmed: 24126512.

7. Karnafel W. Epidemiologia zespołu stopy cukrzycowej. In: Karnafel W. (ed.) Zespół stopy cukrzycowej - patogeneza, diagnostyka, klinika, leczenie. Wydawnictwo Lekarskie PZWL, Warszawa 2013: 3-7.

8. Pawłowski M, Szyłło N. Zespół stopy cukrzycowej. In: Czupryniak L. (ed.) Diabetologia - kompendium. Termedia Wydawnictwa Medyczne, Poznań 2014: 241-267.

9. Zgorzalewicz-Stachowiak M, Zeńczak K, Tomczewska L, et al. Zastosowanie kompleksowej fizjoterapii w uszkodzeniu splotu ramiennego prowadzonej w warunkach uzdrowiskowych. Fizjoterapia. 2013; 21(1): 3-11.

10. Stryła W. Rehabilitacja osób po amputacjach kończyn. In: Kwolek A. (ed.) Rehabilitacja medyczna. Tom II. Wydanie II. Elsevier Urban \& Partner, Wrocław 2013: 317-325.

11. Paprocka-Borowicz M. Ocena skuteczności rehabilitacji i funkcjonowania społecznego pacjentów po amputacji kończyny dolnej. Rozprawa na stopień doktora habilitowanego. Akademia Medyczna we Wrocławiu, Wrocław, Wrocław 2010: 21-41.

12. Hordacre B, Birks V, Quinn S, et al. Physiotherapy rehabilitation for individuals with lower limb amputation: a 15-year clinical series. Physiother Res Int. 2013; 18(2): 70-80, doi: 10.1002/pri.1529, indexed in Pubmed: 22674875. 